\title{
Halomonas elongata, a New Genus and Species of Extremely Salt-Tolerant Bacteria
}

\author{
R. H. VREELAND, ${ }^{1} \dagger$ C. D. LITCHFIELD,${ }^{1} \ddagger$ E. L. MARTIN, ${ }^{2}$ AND E. ELLIOT ${ }^{3}$
}

Department of Microbiology and the Center for Coastal and Environmental Studies, Rutgers-The State University, New Brunswick, New Jersey 08903'; School of Life Sciences, University of Nebraska-Lincoln, Lincoln, Nebraska $68588^{2}$; and Department of Microbiology, University of Maryland, College Park, Maryland $20742^{3}$

The morphological, biochemical, and physiological characteristics of nine bacterial strains isolated from a solar salt facility located on Bonaire, Netherlands Antilles are described. The bacteria were gram-negative rods which produce white, opaque colonies on solid media. During the log phase of growth, the cultures consisted of single and paired cells with polar flagella predominating. Older cultures characteristically produced highly elongated, flexible rods. All of these strains reduced $\mathrm{NO}_{3}$ to $\mathrm{NO}_{2}$, grew anaerobically in the presence of $\mathrm{NO}_{3}$, and fermented glucose but oxidized sucrose, glycerol, mannose, and cellobiose. All strains were ornithine and lysine decarboxylase positive, catalase positive, and cytochrome oxidase negative. Eight of the nine strains grew in a complex Casamino Acids liquid medium containing from 0 to $32 \%(\mathrm{wt} / \mathrm{vol})$ solar salt at temperatures from 23 to $37^{\circ} \mathrm{C}$; the ninth strain was restricted in its growth to 0 to $20 \%$ solar salt. The guanine plus cytosine content of the deoxyribonucleic acid was $61 \pm 1 \mathrm{~mol} \%$. This combination of morphology, salt tolerance, and guanine plus cytosine content supports the establishment of a new genus, Halomonas, in Family II (Vibrionaceae) of part 8, Gram-Negative Facultatively Anaerobic Bacteria, of Bergey's Manual (8th edition). The type species of this genus is $H$. elongata, the type strain of which is isolate $1 \mathrm{H} 9$ (= ATCC 33173). Strain $1 \mathrm{H} 15$ is regarded as belonging to a biovar of $H$. elongata on the basis of its production of lophotrichous cells and its inability to grow at $37^{\circ} \mathrm{C}$ in the presence of $32 \%$ solar salt.

Since the mid-nineteenth century, it has been recognized that bacteria are able to grow in high salt concentrations and are responsible for the reddening of salted fish. These bacteria were found to require high salt concentrations, and later Gibbons noted that the extremely halophilic bacteria could only survive in solutions containing more than $15 \%$ (wt/vol) $\mathrm{NaCl}(3)$. $\mathrm{He}$ suggested that this requirement for salt and the production of red pigment could be used as taxonomic characteristics to classify certain bacteria as extreme halophiles (3). Later, Larsen described a classification system which differentiated slight, moderate, and extreme halophiles on the basis of their upper and lower limits of $\mathrm{NaCl}$ requirements (9). Most of the studies that led to this classification dealt with the red halophilic bacteria.

In 1919, though, LeFevre and Round reported the isolation from cucumber fementation brines of a group of 21 nonpigmented halotolerant bac-

† Present address: Department of Microbiology, School of Life Sciences, University of Nebraska, Lincoln, NE 68588.

† Haskell Laboratory, E.I. du Pont de Nemours and Co., Wilmington, DE 19898. teria. One of their five groups grew in 0 to $15 \%$ $\mathrm{NaCl}$ concentrations, whereas the other four groups of rods exhibited growth over the range of 5 to $25 \% \mathrm{NaCl}(10)$. Recently, Matheson et al. investigated the growth characteristics and internal solute concentration of a halotolerant bacterium that arose as a contaminant on an agar medium originally prepared for extremely halophilic bacteria (13). This isolate has not been further characterized. Meanwhile, Colwell et al. (2) compared the relationship of a group of freshly isolated halophilic bacteria and halotolerant bacteria to a large number of laboratory strains of Halobacterium. The authors found that the freshly isolated and the laboratory strains of Halobacterium were very closely related. The halotolerant bacterial strains, although closely related to one another, showed very little similiarity to the halophilic cultures. This situation prompted a more detailed examination of this group of halotolerant bacteria.

It is the purpose of this paper to describe these halotolerant bacteria further and to define their taxonomic position.

(Portions of this paper were submitted by 
R.H.V. as partial fulfillment of the requirements for an M.S. degree, Rutgers-The State University of New Jersey, New Brunswick, N. J.)

\section{MATERIALS AND METHODS}

Bacterial strains. A list of the strains studied, their dates of isolation, and the environmental salt concentrations of the source materials are shown in Table 1. All isolates were from salterns containing more than $10 \%$ salt and were obtained by direct surface spread plating on the isolation medium. However, media routinely used with the halotolerant isolates contained $8 \%$ (wt/vol) solar salt to distinguish these organisms from the obligate halophiles. This salt concentration has been found to be the optimal salt concentration for the growth of these bacteria regardless of the kind of medium or the growth temperature (Vreeland and Martin, submitted for publication).

Culture maintenance. The medium of Abram and Gibbons (3) was modified as follows: $1,000 \mathrm{ml}$ of distilled water, $1.0 \mathrm{~g}$ of yeast extract (Yeast Products, Inc., Paterson, N.J.), $7.5 \mathrm{~g}$ of Casamino Acids with vitamins (Difco Laboratories, Detroit, Mich.), $5.0 \mathrm{~g}$ of proteose peptone no. $3,3.0 \mathrm{~g}$ of sodium citrate, $20.0 \mathrm{~g}$ of $\mathrm{MgSO}_{4} \cdot 7 \mathrm{H}_{2} \mathrm{O}, 0.005 \mathrm{~g}$ of $\mathrm{Fe}\left(\mathrm{NH}_{4}\right)_{2}\left(\mathrm{SO}_{4}\right)_{2} \cdot 6 \mathrm{H}_{2} \mathrm{O}$, and $7.5 \mathrm{~g}$ of $\mathrm{K}_{2} \mathrm{HPO}_{4}$, supplemented with $80 \mathrm{~g}$ of solar salt produced at the study site (Antilles International Salt Co., Bonaire, Netherlands Antilles). The $\mathrm{pH}$ was adjusted with $\mathrm{NaOH}(1 \mathrm{~N})$ to $8.0 \pm 0.1$ before autoclaving and was 7.5 after autoclaving at $121^{\circ} \mathrm{C}$ for $20 \mathrm{~min}$. When required, agar (Fisher Chemical Co., Springfield, N.J.) was added at $2 \%$ (wt/vol) concentration. The incubation temperature was routinely $30^{\circ} \mathrm{C}$, and stock cultures were stored at $4^{\circ} \mathrm{C}$.

Colonial morphology. Colonial morphology was described after growth for 7 to 14 days on the casein medium described previously (2).

Gram reaction and motility. Cultures from broth and solid media were examined both by normal procedures and by a modification of these procedures (14). A $20 \%$ (wt/vol) solar salt solution was used to wash the smears between each step, and decolorization was accomplished with acetone-ethanol (50:50, vol/ vol). Wet mounts were prepared for motility determi-

\section{TABLE 1. List of salt-tolerant strains used in this} study ${ }^{a}$

\begin{tabular}{ccc}
\hline $\begin{array}{c}\text { Strain } \\
\text { no. }\end{array}$ & $\begin{array}{c}\text { Date } \\
\text { isolated }\end{array}$ & $\begin{array}{c}\text { Environmental } \\
\text { salt concn }^{b}\end{array}$ \\
\hline IH3 & June 1974 & 12.8 \\
$1 \mathrm{H} 6$ & June 1974 & 18.6 \\
$1 \mathrm{H} 9$ & June 1974 & 25.6 \\
$1 \mathrm{H} 11$ & June 1974 & 18.6 \\
$1 \mathrm{H} 12$ & June 1974 & 18.6 \\
$1 \mathrm{H} 14$ & June 1974 & 18.6 \\
$1 \mathrm{H} 15$ & June 1974 & 15.4 \\
$1 \mathrm{H} 19$ & June 1974 & 15.4 \\
$2 \mathrm{H} 17$ & Oct. 1974 & 21.0 \\
\hline
\end{tabular}

${ }^{a}$ All strains were isolated on complex casein medium (2) containing $25 \%$ solar salt (wt/vol).

${ }^{b}$ Samples were obtained from condensers at the Antilles International Salt Co. facility on Bonaire, Netherlands Antilles. nation from various growth stages and were examined by light microscopy and phase-contrast microscopy. The cultures used for staining varied from early log through the stationary growth phase and were consistent with respect to their Gram reaction.

Electron microscopy: flagellar arrangement and fine structure. The flagellar arrangement of the seven viable strains was examined by staining with $2 \%$ uranyl acetate. Log-phase cells in broth culture were transferred onto Formvar-coated grids by dipping the grids into the cell suspension. The grids were then dipped rapidly into the stain, excess stain was removed with filter paper, and the grids were air-dried overnight.

The fine structure and type of cell division of strain 1H9 were examined via transmission electron microscopy. The cells were harvested from both mid-log and stationary-phase cultures. For the initial fixation, the cell pellet was suspended in $3 \%$ glutaraldehyde in phosphate buffer for $2 \mathrm{~h}$ at room temperature. The cells were then suspended in $2 \%$ ion agar and postfixed in $\mathrm{OsO}_{4}$ for $1 \mathrm{~h}$ followed by $2 \%$ uranyl acetate for $1 \mathrm{~h}$. The cell preparations were then dehydrated with acetone and embedded in Epon 812 resin. Thin sections were made with an LKB ultramicrotome (LKB Co., Rockville, Md.) fitted with a diamond knife. The sections were stained with uranyl acetate and lead citrate solutions. Micrographs were obtained from a Phillips EM 201 (Phillips Co., Eindhoven, Holland) transmission electron microscope with Kodak electron microscope film 4489 (Estar thick base).

Carbohydrate reactions. The oxidative or fermentative utilization of various carbohydrates was studied with the bromothymol blue medium of Holding and Collee (5). Basal bromothymol blue medium was prepared with $8 \%$ solar salt (wt/vol) and supplemented before autoclaving with $0.5 \%$ sucrose, glycerol, mannose, cellobiose, gluconate, glucose, or lactose. Representative strains $(1 \mathrm{H} 15,1 \mathrm{H} 11$, and $1 \mathrm{H} 9)$ were also tested for their ability to use the same sugars as sole carbon sources when $0.5 \%$ (wt/vol) of the filtersterilized solutions was added to sterile chemically defined medium composed of $5.3 \mathrm{~g}$ of $\mathrm{MgCl}_{2} \cdot 6 \mathrm{H}_{2} \mathrm{O}, 0.8$ $\mathrm{g}$ of $\mathrm{KCl}, 4.0 \mathrm{~g}$ of $\left(\mathrm{NH}_{4}\right)_{2} \mathrm{SO}_{4}, 0.6 \mathrm{~g}$ of $\mathrm{K}_{2} \mathrm{HPO}_{4} \cdot 3 \mathrm{H}_{2} \mathrm{O}$, $0.04 \mathrm{~g}$ of $\mathrm{Fe}\left(\mathrm{NH}_{4}\right)_{2}\left(\mathrm{SO}_{4}\right)_{2} \cdot 6 \mathrm{H}_{2} \mathrm{O}$, and $80 \mathrm{~g}$ of $\mathrm{NaCl}$ in $1,000 \mathrm{ml}$ of distilled water, $\mathrm{pH} 7.0$, after autoclaving. The oxidative or fermentative metabolism of glucose was also determined in the medium of Hugh and Leifson (6) to which $8 \%$ solar salt was added in the tubes.

Biochemical tests. The ability of the strains to hydrolyze starch was detected on $0.5 \%$ (wt/vol) corn starch medium, which, after growth had occurred, was flooded with Gram iodine solution; clearing around the growth indicated the hydrolysis of starch. Proteolytic capability was examined using $12.0 \%$ (wt/vol) nutrient gelatin (Difco) and the casein medium previously described (2). Casein hydrolysis was presumed when clear zones appeared around the colonies. Protein hydrolysis was confirmed when the clear zones persisted after flooding the plate with $0.01 \%$ amido black in $7.5 \%$ acetic acid. Gelatin liquefaction was considered positive if the inoculated medium failed to solidify after sufficient incubation followed by cooling to $4^{\circ} \mathrm{C}$. The tests performed with the Patho-Tec Rapid 
ID System (Warner Lambert, Morris Plains, N.J.) were for cytochrome oxidase, reduction of nitrate to nitrite, phenylalanine deaminase, lysine decarboxylase, production of $\mathrm{H}_{2} \mathrm{~S}$ from cysteine, production of indole from tryptophan, acetylmethylcarbinol (VogesProskauer test), urease production, esculin hydrolysis, malonate utilization, ornithine decarboxylase, and production of $\beta$-galactosidase. The use of the test strips was adopted after their comparison with traditional media showed them to be less susceptible to interference from the high salt concentrations. Methyl red tests were performed after growth of the test organism in methyl red-Voges-Proskauer medium (Difco) rehydrated with the appropriate salt solution. The results of all tests involving media and indicators were considered negative if no reaction or growth had occurred by 14 days after the time required to grow the organisms under optimal conditions.

Oxygen requirements. The oxygen requirements of the organisms were determined with thioglycollate medium (Difco) rehydrated with $8 \%$ solar salt solution (wt/vol) and by the growth on the casein medium in a candle jar. Additional studies included incubation on maintenance medium prepared with and without $0.1 \%$ $\mathrm{KNO}_{3}$ in anaerobic jars (BBL Microbiology Systems, Baltimore, Md.), where anaerobic conditions were created with $\mathrm{CO}_{2}$ and $\mathrm{H}_{2}$ and were monitored with standard BBL indicator strips.

Nitrogen requirements. The nitrogen requirements were determined in media containing $\mathrm{KNO}_{3}$, $\left(\mathrm{NH}_{4}\right)_{2} \mathrm{SO}_{4}$, Casamino Acids, or casein.

pH range. The $\mathrm{pH}$ range for growth of each isolate was tested at $30^{\circ} \mathrm{C}$ in broth maintenance medium at the usual salt concentration. The test $\mathrm{pH}$ values, before sterilization, were: $4.0,5.0,6.0,7.0,8.0$, and 9.0; they remained at $\pm 0.1 \mathrm{pH}$ unit after autoclaving.

Antibiotic susceptibility. The antibiotic susceptibility of all strains was determined on surface-seeded maintenance medium and with susceptibility disks obtained from Difco except for those containing the Vibriostat agent, $0 / 129$, and $\mathrm{HgCl}_{2}$, which were prepared in our laboratory. The following antibiotics were used: streptomycin $(10 \mu \mathrm{g})$, penicillin $(10 \mathrm{U})$, ampicillin (30 U), chloramphenicol (30 U), tetracycline (30 U), novobiocin (30 U), neomycin (30 U), bacitracin (10 U), and nalidixic acid ( $30 \mathrm{U})$. In addition, susceptibility to mercurials was similarly tested with $\mathrm{HgCl}_{2}(1: 5,000)$.

DNA base composition. The guanine plus cytosine $(\mathrm{G}+\mathrm{C})$ content of the deoxyribonucleic acid (DNA) was determined by the thermal denaturation procedure of Mandel et al. (11). Log-phase cells of $1 \mathrm{H} 9$ and $1 \mathrm{H} 15$ were ruptured, and the DNA was recovered by the method of Marmur (12). Stationary-phase cells were highly resistant to breakage procedures, even those which included various surfactants.

Salt and temperature ranges for growth. The isolates were tested for their ability to grow in broth maintenance medium at different temperatures and salt concentrations. The temperatures were: $4,15,23$, 30,37 , and $45^{\circ} \mathrm{C}$, and the solar salt concentrations tested were $0,3.5,8.0,15.0,20.0$, and $32.0 \%$ (wt/vol). After 3 weeks, all of the tubes without visible growth, along with those in which growth was questionable, were placed for an additional 4 weeks at $30^{\circ} \mathrm{C}$ to determine whether the apparent inhibition had ac- tually been lethal to the bacterium. Organisms which were able to resume active growth during this period were considered to have survived the exposure to the inhibitory salt and temperature conditions, whereas those organisms that did not show a return to active growth were considered killed by that individual salt or temperature condition or both.

Computer analysis. Both $S_{J}$ and $S_{M}$ single-linkage analyses of the strain data were performed at the University of Maryland; the programs used were developed by R. R. Colwell.

\section{RESULTS}

Morphology. The isolates were rod-shaped organisms which occurred both singly and in pairs during the log phase of growth (Fig. 1). Transmission electron microscopy of negatively stained cells (Fig. 2) showed that these cells have a typical gram-negative cell wall structure and that both curved and straight forms were present in all preparations (Fig. 1 and 2). Stationaryphase cells from the maintenance medium produced elongated, flexuous filaments of varying lengths (Fig. 1 and 2). This elongation appears to be the result of the faster growth rates obtained in shake flasks and not, as originally thought, of increased oxygen tension (Vreeland, Martin, and Litchfield, unpublished data). When isolates were grown in a chemically defined, amino acid-vitamin medium, only about $25 \%$ of the cells showed elongation.

Cell division occurred via fission (Fig. 2) and appeared to be apical and transverse in the elongated cells (Fig. 1c).

The short cells were motile and were either polarly flagellated or peritrichous (Fig. 3). Negative staining with uranyl acetate showed the position of attachment and position of the flagella on $1 \mathrm{H} 9,1 \mathrm{H} 11$, and $1 \mathrm{H} 15$ when viewed by transmission electron microscopy (Fig. 3).

Colonial morphology. On a complex solid medium, these bacteria produced smooth, glistening, opaque, white colonies about $2 \mathrm{~mm}$ in diameter. After $24 \mathrm{~h}$ the colonies began to spread, apparently as the numbers of the long, flexuous filaments increased, but they still were less than $4 \mathrm{~mm}$ in diameter.

Cultural and physiological characteristics. The isolates were gram negative by conventional and by modified Gram-staining techniques. The specific biochemical and physiological characteristics of the strains are listed in Table 2. They reduced $\mathrm{NO}_{3}$ to $\mathrm{NO}_{2}$ and were able to grow anaerobically in the presence of $\mathrm{NO}_{3}$ (Table 2). They were catalase positive, Kovac oxidase positive, and ornithine and lysine decarboxylase positive; utilized malonate; fermented glucose; and oxidized glycerol, sucrose, mannose, and cellobiose. Most of the strains also oxidized lactose and gluconate. None of the 

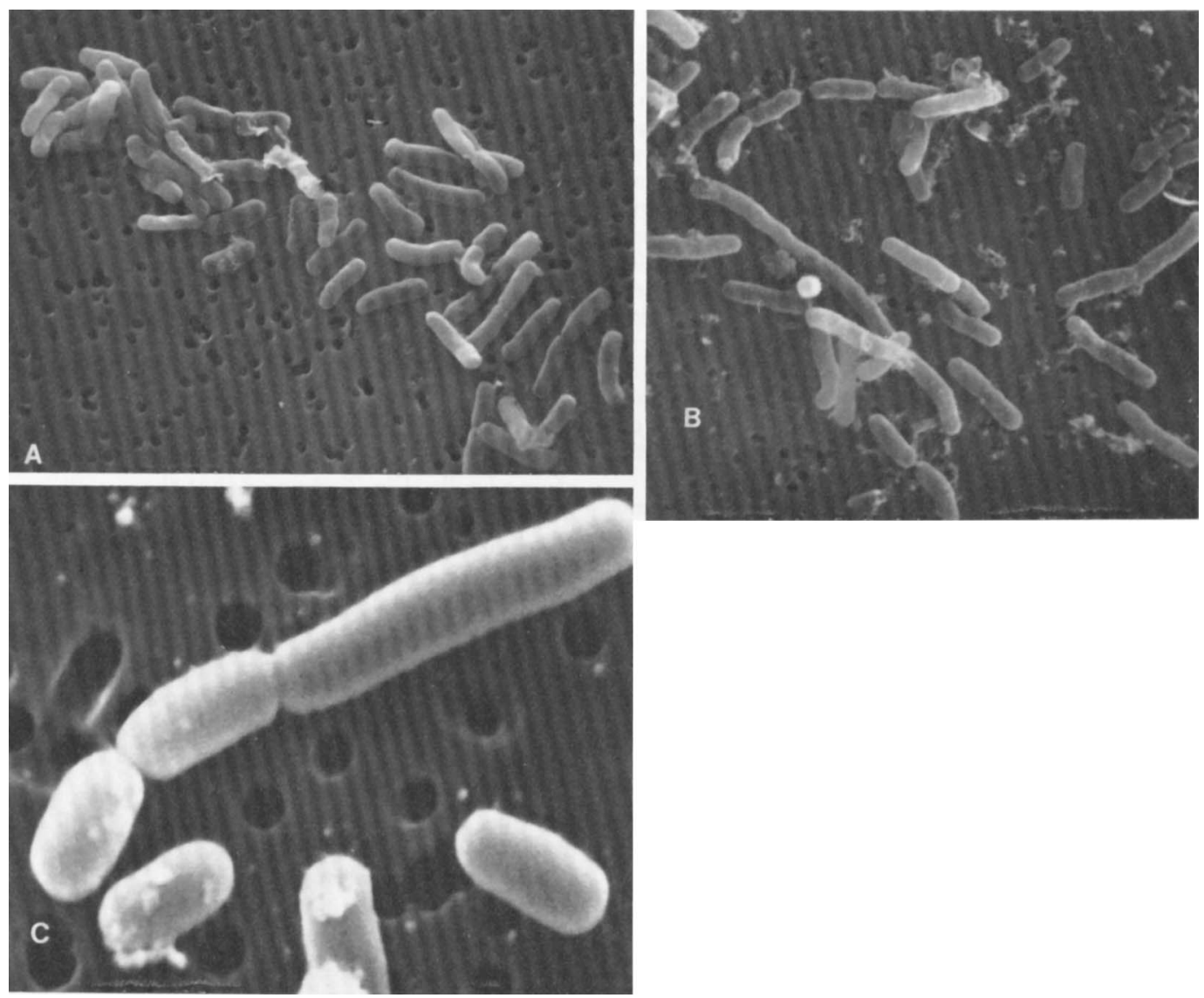

FIG. 1. Morphology of selected cells of the salt-tolerant isolate 1H9. Scanning electron photomicrographs of cells grown in the complex casein medium (2): (A) with shaking $(\times 4,300)$; (B) from the same medium but under stationary conditions $(\times 4,300)$. (C) An enlargement of an elongated cell from the same culture undergoing two divisions $(\times 15,650)$.

strains produced $\mathrm{H}_{2} \mathrm{~S}$ from cysteine, hydrolyzed starch or casein, or liquefied agar. Phenylalanine deaminase and cytochrome oxidase were not produced, according to the tests employed (Table 2).

All of the strains were susceptible to $\mathrm{HgCl}_{2}$ and chloromycetin and showed only slight susceptibility to penicillin, streptomycin, tetracycline, ampicillin, vibriostat $0 / 129$, novobiocin, neomycin, bacitracin, or nalidixic acid (Table 2).

pH range for growth. The broth maintenance medium was adjusted to $\mathrm{pH} 4$ to 9 before autoclaving and was checked afterwards to assure the same $\mathrm{pH}$ levels. All nine isolates were able to grow over the $\mathrm{pH}$ range 5 to 9 , but none grew at $\mathrm{pH} 4$ (Table 2).

Salt and temperature tolerance. The salt and temperature tolerance tests performed on the nine isolates (Table 3 ) showed that these organisms were able to grow over a wide range of temperature and salt concentrations. All nine isolates consistently grew, or at least survived, in salt concentrations from 3.5 to $20 \%$ added solar salt and at temperatures ranging from 4 to $45^{\circ} \mathrm{C}$. Only one strain, $1 \mathrm{H} 15$, was unable to survive in $32 \%$ solar salt at any temperature. At $32 \%$ solar salt and $45^{\circ} \mathrm{C}$, most of the strains were killed. The only strain which survived under this condition was strain 1H9. The best growth and the greatest tolerance to various salt levels were achieved at $30^{\circ} \mathrm{C}$. This temperature allowed all nine strains to grow well in the maintenance medium containing no added salt as well as in maintenance medium containing $20 \%$ solar salt. Eight strains also grew well in maintenance medium with $32 \%$ solar salt and at $30^{\circ} \mathrm{C}$.

When the other growth-promoting temperatures were examined in terms of their ability to promote salt tolerance, the following order was noted: $30^{\circ} \mathrm{C}>23^{\circ} \mathrm{C}, 37^{\circ} \mathrm{C}>15^{\circ} \mathrm{C}>45^{\circ} \mathrm{C}>$ 

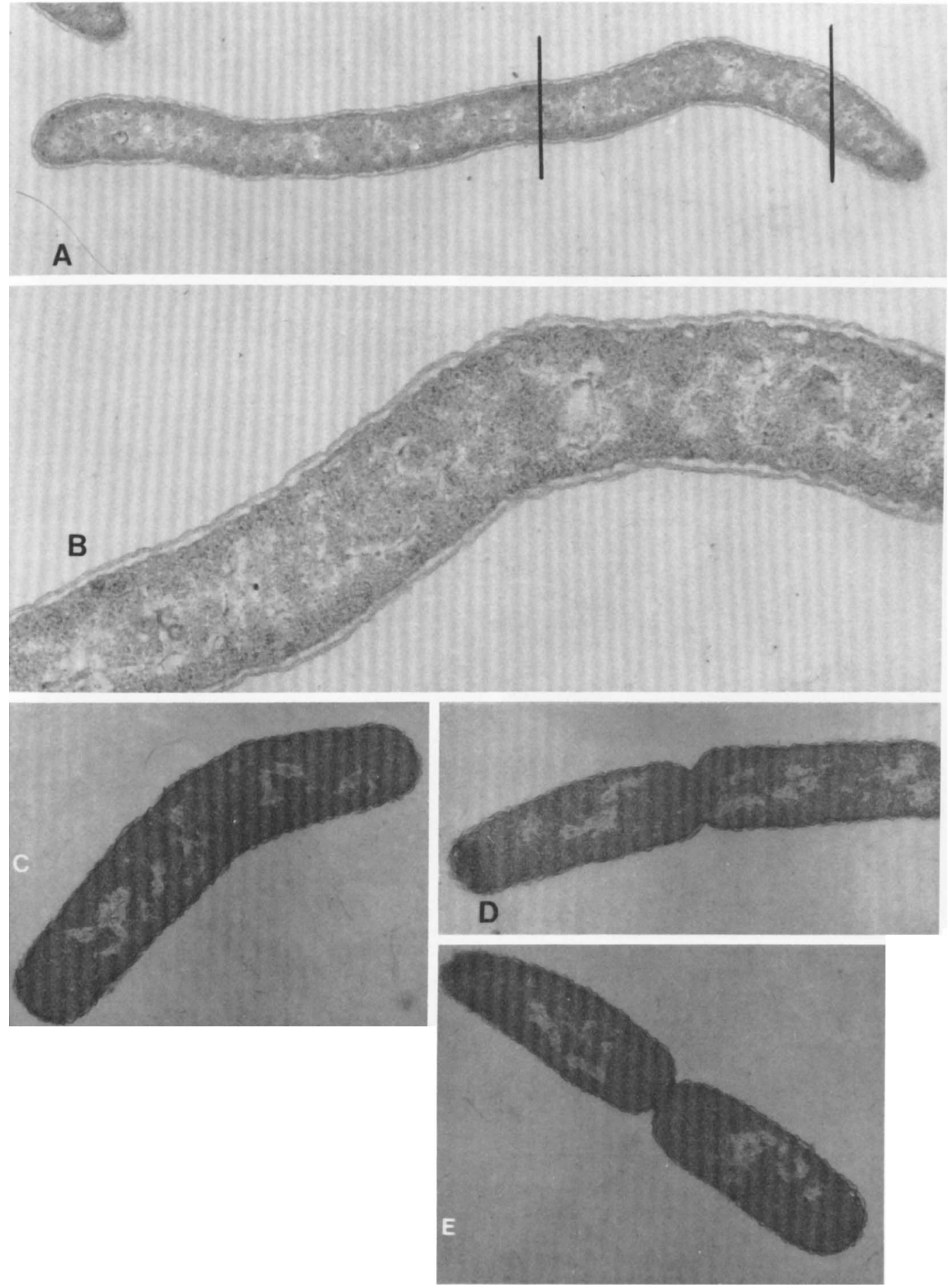

Fig. 2. Thin-section transmission electron photomicrographs of strain 1 H9 showing cell elongation (A and $B)$ and division of the short form (C to $E$ ) found during growth on the complex casein medium under conditions of shaking. (A) One large cell $(\times 22,300)$; (B) An enlargement of the marked area in $A(70,400 \times)$. (C to E) The sequential division of the short forms of $1 \mathrm{H} 9(\times 15,800)$. 


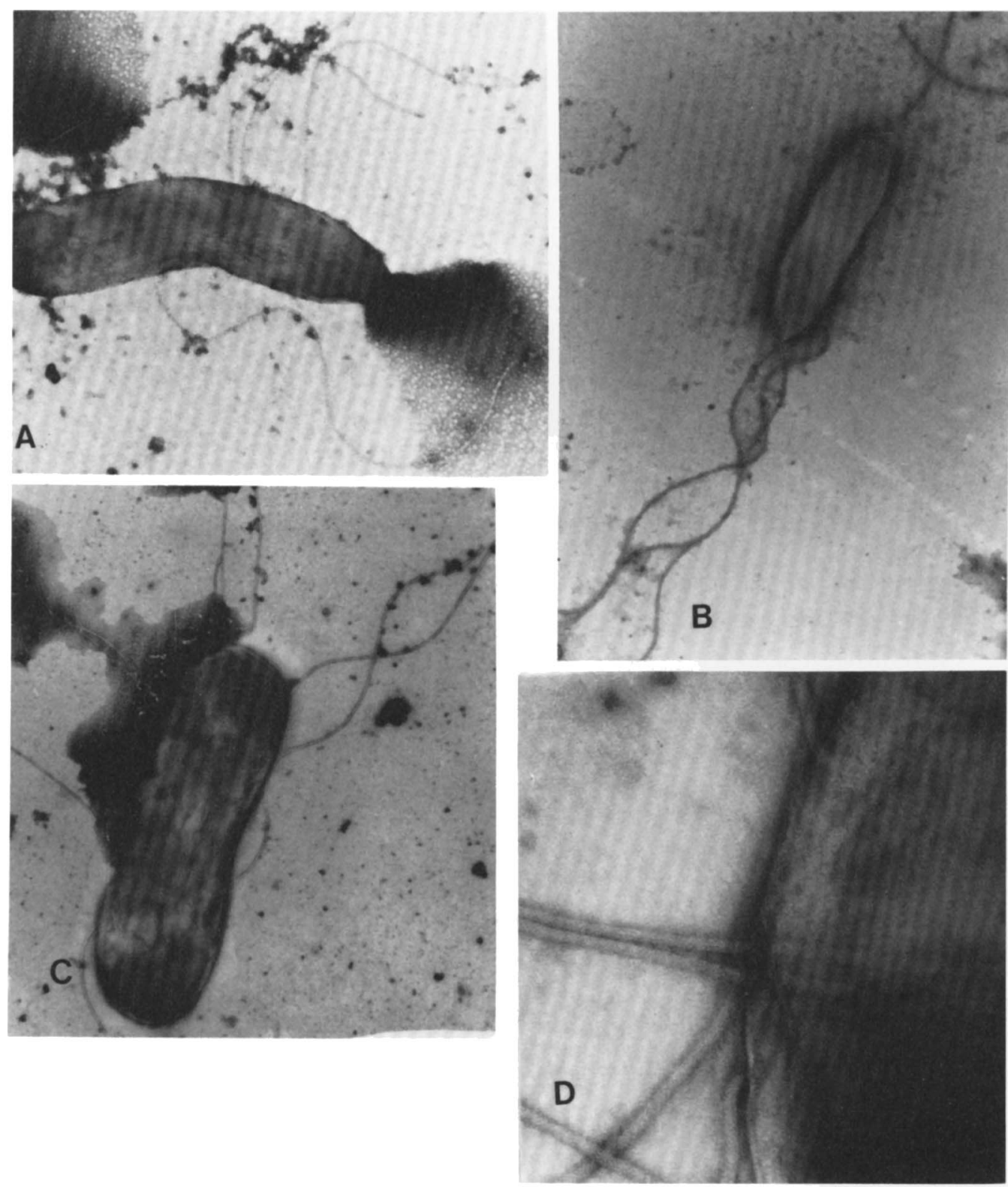

FIG. 3. Transmission electron photomicrographs of uranyl acetate-stained cells showing flagellar arrangements and attachment. (A) strain 1H9; (B) 1H11; (C) 1H15-all at $\times 17,200$. (D) An enlargement of the flagellar attachments of a cell of strain 1 H15 (×103,700).

$4^{\circ} \mathrm{C}$. The lowest temperature tested, $4^{\circ} \mathrm{C}$, was found to inhibit growth of seven strains, but when the cultures were returned to $30^{\circ} \mathrm{C}$ for an additional 28-day incubation, all had survived the low temperature at the 0 or $3.5 \%$ solar salt levels (Table 3).

At the lowest temperature tested, $4^{\circ} \mathrm{C}$, none of the isolates grew with 0 or $3.5 \%$ solar salt, but $1 \mathrm{H} 14$ and $1 \mathrm{H} 9$ grew at this temperature when salt concentrations were 8 to $20 \%$. Further research on the salt tolerance of strain $1 \mathrm{H} 9$ and its relationship to temperature and type of medium will be described elsewhere (Vreeland and Martin, submitted for publication).

Carbon source tests. Representative strains were selected for further examination of the individual carbon sources which could be metabolized. Strains $1 \mathrm{H} 9,1 \mathrm{H} 11$, and $1 \mathrm{H} 15$ were able 
TABLE 2. Biochemical and morphological characteristics of the halotolerant bacteria

\begin{tabular}{|c|c|c|c|c|c|c|c|c|c|}
\hline \multirow{2}{*}{ Characteristic } & \multicolumn{9}{|c|}{ Strain designation ${ }^{a}$} \\
\hline & $1 \mathrm{H15}$ & IH14 & $1 \mathrm{H} 12$ & $1 \mathrm{H} 9$ & $2 \mathrm{H} 17$ & $1 \mathrm{H} 6$ & 1H3 & $1 \mathrm{H} 19$ & $1 \mathrm{H} 11$ \\
\hline Cells rod shaped & + & + & + & + & - & - & - & + & + \\
\hline Cells curved rods & + & + & - & - & - & - & - & + & + \\
\hline Cells long, flexuous rods & + & + & + & + & + & + & + & + & + \\
\hline Squared ends & - & - & - & - & - & - & - & - & + \\
\hline Rounded ends & + & + & + & + & - & + & + & + & - \\
\hline Gram negative & + & + & + & + & + & + & + & + & + \\
\hline Motile (flagellar) & + & + & + & + & + & + & + & $d$ & + \\
\hline Motile (flexing rods) & + & + & + & + & + & + & + & + & + \\
\hline Single cells & + & + & + & + & + & + & + & + & + \\
\hline Paired cells & + & + & + & + & + & + & + & + & + \\
\hline Short chains & + & + & - & + & - & + & + & + & + \\
\hline Colony $<2 \mathrm{~mm}$ (diam) & + & + & + & + & + & + & + & + & + \\
\hline Raised colonies & + & - & - & - & - & + & + & + & - \\
\hline Convex colonies & - & + & + & + & + & - & - & - & - \\
\hline Entire edges & + & + & + & - & + & + & - & - & + \\
\hline Crenated edges & - & - & - & + & - & - & + & + & - \\
\hline Opaque colonies & + & + & + & + & + & + & + & + & + \\
\hline White colonies & + & + & + & + & + & + & + & + & + \\
\hline $\begin{array}{l}\text { Growth in thioglycollate } \\
\text { (surface) }\end{array}$ & + & + & + & + & - & + & + & + & + \\
\hline Lycine decarboxylase & + & + & + & + & + & + & + & + & + \\
\hline Ornithine decarboxylase & + & + & + & + & + & + & + & + & + \\
\hline Urease produced & + & + & - & + & + & + & - & - & + \\
\hline $\mathrm{NO}_{3}$ reduced to $\mathrm{NO}_{2}$ & + & + & + & + & + & + & + & + & + \\
\hline Gelatin liquefied & + & + & - & + & - & - & - & + & - \\
\hline Catalase positive & + & + & + & + & + & + & + & + & + \\
\hline Cytochrome oxidase & - & - & - & - & - & - & - & - & - \\
\hline Kovac's oxidase & + & + & + & + & $d$ & + & + & + & + \\
\hline Esculin hydrolyzed & + & + & + & + & - & - & + & - & - \\
\hline Malonate utilized & + & + & + & + & + & + & + & + & + \\
\hline$\beta$-Galactosidase produced & + & - & - & - & + & - & $\begin{array}{l}+ \\
-\end{array}$ & - & \\
\hline \multicolumn{10}{|l|}{ Susceptibility to: } \\
\hline Penicillin & - & - & - & - & $\mathrm{d}$ & + & - & + & - \\
\hline Streptomycin & - & - & - & - & + & - & - & - & - \\
\hline $\mathrm{HgCl}_{2}$ & + & + & + & + & + & + & + & + & + \\
\hline Tetracycline & - & - & - & - & $\mathrm{d}$ & - & + & - & - \\
\hline Ampicillin & - & - & + & - & d & - & - & + & + \\
\hline Nalidixic acid & - & - & - & - & $\mathrm{d}$ & - & - & - & - \\
\hline Bacitracin & - & - & - & - & d & + & - & + & - \\
\hline Novobiocin & - & - & - & - & d & - & + & + & - \\
\hline Neomycin & - & - & + & - & d & - & - & - & - \\
\hline Chloromycetin & + & + & - & + & + & + & + & + & + \\
\hline Glucose fermented & + & + & + & + & + & + & + & + & + \\
\hline Lactose oxidized & + & + & + & + & + & - & - & - & + \\
\hline Lactose alkaline & - & - & - & - & - & + & + & + & - \\
\hline Glycerol oxidized & + & + & + & + & + & + & + & + & + \\
\hline Sucrose oxidized & + & + & + & + & + & + & + & + & + \\
\hline Mannose oxidized & + & + & + & + & + & + & + & + & + \\
\hline Cellobiose oxidized & + & + & + & + & + & + & + & + & + \\
\hline Gluconate oxidized & - & - & + & + & + & + & + & + & + \\
\hline Growth pH 5.0-9.0 & + & + & + & + & + & + & + & + & + \\
\hline
\end{tabular}

\footnotetext{
${ }^{a}+$, Positive or present for the organism listed; - , negative or absent for the organism listed; $d$, test not done.
}

to utilize glucose, gluconate, glycerol, lactose, mannose, and sucrose as their sole sources of carbon (Table 4). Additionally, 1 H9 was tested and was found to grow with cellobiose, succinate, mannitol, alanine, and glutamine as sole carbon sources.

DNA base composition. The $\mathrm{G}+\mathrm{C}$ contents of the DNAs of strains $1 \mathrm{H} 9$ and $1 \mathrm{H} 11$ were 60.5 
TABLE 3. Tolerance of salt-tolerant strains to various temperature and salt conditions

\begin{tabular}{|c|c|c|c|}
\hline \multirow{2}{*}{$\begin{array}{l}\text { Incu- } \\
\text { bation } \\
\text { temp } \\
\left({ }^{\circ} \mathrm{C}\right)^{a}\end{array}$} & \multirow{2}{*}{$\begin{array}{c}\text { \% Solar } \\
\text { salt } \\
(\mathrm{wt} / \mathrm{vol})^{b}\end{array}$} & \multicolumn{2}{|c|}{$\%$} \\
\hline & & Growth & Survival \\
\hline \multirow[t]{6}{*}{4} & 0 & 0 & 100 \\
\hline & 3.5 & 0 & 100 \\
\hline & 8.0 & 22.2 & 77.8 \\
\hline & 15.0 & 22.2 & 77.8 \\
\hline & 20.0 & 11.1 & 88.8 \\
\hline & 32.0 & 0 & $66.6^{c}$ \\
\hline \multirow[t]{6}{*}{15} & 0 & 44.4 & 55.6 \\
\hline & 3.5 & 100 & NA \\
\hline & 8.0 & 100 & NA \\
\hline & 15.0 & 100 & NA \\
\hline & 20.0 & 100 & NA \\
\hline & 32.0 & 0 & $66.6^{\mathrm{c}}$ \\
\hline \multirow[t]{6}{*}{23} & 0 & 100 & NA \\
\hline & 3.5 & 100 & NA \\
\hline & 8.0 & 100 & NA \\
\hline & 15.0 & 100 & NA \\
\hline & 20.0 & 100 & NA \\
\hline & 32.0 & $77.8^{c}$ & 0 \\
\hline \multirow[t]{6}{*}{30} & 0 & 100 & NA \\
\hline & 3.5 & 100 & NA \\
\hline & 8.0 & 100 & NA \\
\hline & 15.0 & 100 & NA \\
\hline & 20.0 & 100 & NA \\
\hline & 32.0 & $88.9^{c}$ & 0 \\
\hline \multirow[t]{6}{*}{37} & 0 & 100 & NA \\
\hline & 3.5 & 100 & NA \\
\hline & 8.0 & 100 & NA \\
\hline & 15.0 & 100 & $\mathrm{NA}$ \\
\hline & 20.0 & 100 & NA \\
\hline & 32.0 & 66.6 & $11.1^{c}$ \\
\hline \multirow[t]{6}{*}{45} & 0 & 0 & $88.9^{c}$ \\
\hline & 3.5 & $88.9^{\circ}$ & 0 \\
\hline & 8.0 & $88.9^{c}$ & 0 \\
\hline & 15.0 & 100 & NA \\
\hline & 20.0 & 88.9 & 11.1 \\
\hline & 32.0 & 0 & 11.1 \\
\hline
\end{tabular}

${ }^{a}$ Incubation was under stationary conditions.

${ }^{b}$ The solar salt was incorporated in the broth maintenance medium.

' No growth after 28 days after transfer to $30^{\circ} \mathrm{C}$; culture assumed to be dead. Abbreviation: NA, Not applicable.

$\pm 0.5 \mathrm{~mol} \%$ as determined by buoyant density or thermal denaturation curves or both $(11,12)$.

Taxonomic interrelationships. Featurefrequency analysis of all of the tests performed on these bacteria indicated that the following characteristics are distinctive to all members of this group (Table 5). All are gram-negative, rodshaped cells with flexuous filaments during the stationary growth phase, and all produce small white colonies on solid media. They produce a heavy, even turbidity in broth at $\mathrm{pH} 5$ to 9 and can grow over the salt range of 0 to $32 \%$ solar salt at a temperature of $30^{\circ} \mathrm{C}$. They are catalase and Kovac's oxidase positive and are able to reduce nitrate and grow anaerobically when $\mathrm{NO}_{3}$ is present. They ferment glucose and oxidize other sugars. Ornithine and lysine are decarboxylated, but the metabolism of other substrates differs widely among the strains. The only antimicrobial compound to which all are susceptible is mercuric chloride.

Cluster analysis on the basis of positive matches resulted in the matrix shown in Fig. 4. The overall similarity was greater than $80 \%$, with strains $1 \mathrm{H} 14$ and $1 \mathrm{H} 15$ demonstrating $100 \%$ similarity to each other, whereas $1 \mathrm{H} 19$ was $100 \%$ similar to $1 \mathrm{H} 15$. When examined via the $S_{M}$ matching coefficient, the level of similarity of these three strains decreased somewhat due to differences in urease production, gluconate oxidation, and susceptibility to ampicillin.

A dendrogram (Fig. 5) depicting the interrelatedness of the strains emphasizes their intragroup homogeneity. Further analysis revealed that strain $1 \mathrm{H} 9$ possessed $96.5 \%$ similarity to the computer-determined hypothetical mean organism (HMO), and this strain was therefore considered to be most representative of the group.

\section{DISCUSSION}

Based on the natural environment of the halotolerant bacteria, their ability to grow well in high salt concentrations, and a demonstrated requirement for sodium ions (Vreeland and Martin, submitted for publication), it would seem advantageous to place these organisms in a taxonomic position close to that of the Halobacteriaceae. However, in a major study of the taxonomy of the obligately halophilic bacteria, Colwell et al. (2) showed clearly that there is little similarity between these two groups of bacteria,

TABLE 4. Utilization ${ }^{a}$ of carbon sources by representative strains

\begin{tabular}{lccc}
\hline \multirow{2}{*}{ Carbon source $^{b}$} & \multicolumn{3}{c}{ Strain } \\
\cline { 2 - 4 } & $1 \mathrm{H} 9$ & $1 \mathrm{H} 11$ & $1 \mathrm{H} 15$ \\
\hline Glucose & + & + & + \\
Gluconate & + & + & + \\
Glycerol & + & + & + \\
Lactose & + & \pm & + \\
Mannose & + & + & + \\
Sucrose & + & + & + \\
Cellobiose & + & \pm & + \\
Succinate & + & NT & NT \\
Mannitol & + & NT & NT \\
Alanine & + & NT & NT \\
Glutamine & + & NT & NT \\
No additional carbon source & - & - & - \\
\hline
\end{tabular}

\footnotetext{
${ }^{a}$ Growth was estimated visually.

${ }^{b}$ Basal medium contained $8 \% \mathrm{NaCl}, 0.4 \%\left(\mathrm{NH}_{4}\right)_{2} \mathrm{SO}_{4}$ as nitrogen source, and other compounds, as described in the text. Symbols: -, No visible growth; \pm , slight growth; +, excellent growth; NT, not tested.
} 
TABLE 5. Feature frequency of the biochemical and morphological characteristics of the nine halotolerant strains studied

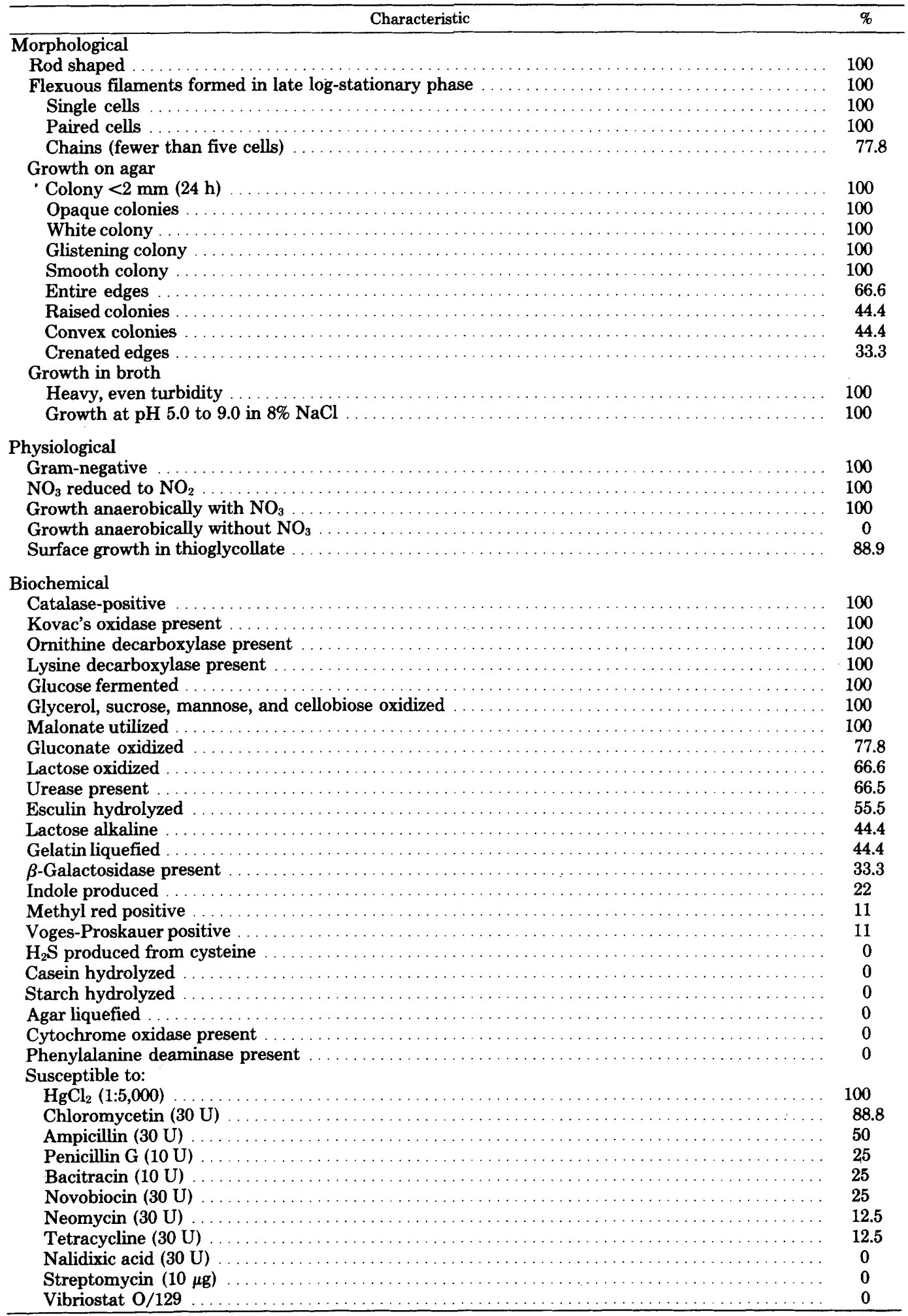




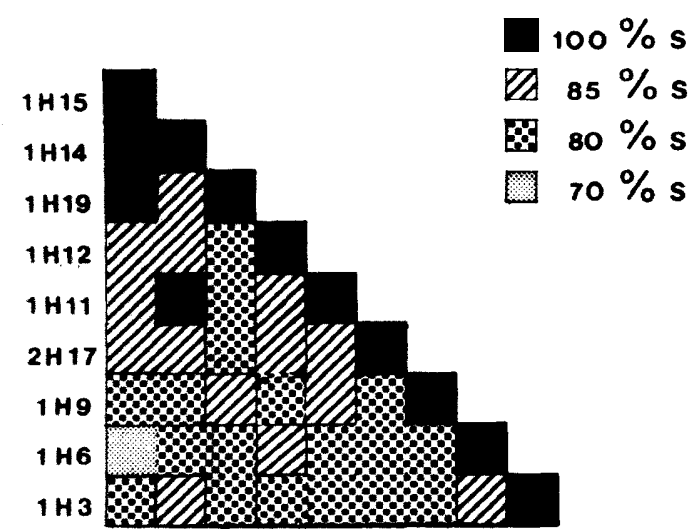

FIG. 4. Similarity matrix based on positive matches for the nine halotolerant strains studied.

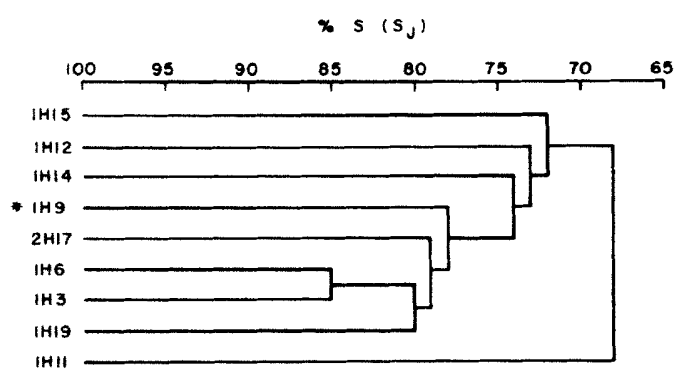

FIG. 5. Dendrogram showing the interrelatedness of the halotolerant isolates based upon the $\$_{J}$ matching coefficient. The asterisk designates the type strain, $1 \mathrm{H} 9$, selected on the basis of its similarity to the hypothetical mean organism.

less than $40 \%$. A further restriction to such placement is that the organisms described in this paper have a typical gram-negative cell wallmembrane complex (Fig. 2), and, unlike the halobacteria (9), they do not contain carotenoid pigments but possess fatty acids and diacylphospholipids instead of glyceryl-ether lipids (Kiefer and Litchfield, unpublished data). Unusual cell wall and lipid compositions are all requirements for inclusion with the Halobacteriaceae (1).

The variety of irregularly spaced bends and convolutions present in the cells of this unusual group of bacteria (Fig. 1 and 2) would indicate that these strains are flexible. This flexibility, plus the high degree of motility, a characteristic spinning motion, and the high $\mathrm{G}+\mathrm{C}$ value might argue that these isolates are related to such genera as Spirillum, Aquaspirillum, Oceanospirillum (7), and Serpens (4). Certainly, it seems possible that they could be included in this group. However, the fermentative attack on glucose, anaerobic growth on nitrate, presence of urease, and especially the lack of cytochrome oxidase would all seem to argue against the inclusion of the isolates described here as members of any of these genera (8).

There is one other group of bacteria which are known to have curved cells, variable flagellation, and mixed attacks on different carbohydrates: the Vibrionaceae, Family II, Part 8 of Bergey's Manual (1). Besides the already mentioned characteristics, the family is also described as facultatively anaerobic, with a nonexacting nutrition, often isolated from freshwater and seawater, and with $\mathrm{G}+\mathrm{C}$ values ranging from 39 to $63 \mathrm{~mol} \%$ (1). However, the group of halotolerant isolates described here cannot be adequately accommodated in any of the existing genera in this family. Justification for the establishment of a new genus for these organisms, therefore, is based on the following characteristics distinctive to this group: nonsusceptibility to the vibriostat agent $(0 / 129)$, negative cytochrome oxidase test, extreme salt tolerance, distinctive morphology cycle, glucose fermentation, flexible motility, and high $\mathrm{G}+\mathrm{C}$ content of the DNA. We therefore propose for these organisms the establishment of a new genus, Halomonas, in the family $\mathrm{Vi}$ brionaceae.

Halomonas gen. nov. (Gr. n. hals, halos salt, the sea; Gr. monas small rod; M. L. fem. n. Halomonas the salt short rods).

Cells are rod shaped and occur singly or in pairs in the logarithmic phase of growth. Elongated, flexuous rods are produced during the stationary growth phase in complex medium. In chemically defined media, shorter flexuous rods are observed in approximately $25 \%$ of the cultures.

Gram negative. Motile. Flagellar arrangement depends on the strain, but it is either lateral or polar. On solid, complex media containing $8 \%$ salt, colonies are white to cream, opaque, and less than $2 \mathrm{~mm}$ in diameter; spreading may occur after extended incubation.

Facultatively anaerobic. $\mathrm{NO}_{3}$ is reduced to $\mathrm{NO}_{2}$. Catalase positive; generally Kovac oxidase positive, but all strains are cytochrome oxidase negative. Ornithine and lysine are decarboxylated, but phenylalanine is not deaminated; $\mathrm{H}_{2} \mathrm{~S}$ is not produced from cysteine; and casein and starch are not usually hydrolyzed.

Glucose is fermented without gas production. Glycerol, sucrose, mannose, and cellobiose are oxidized. These carbohydrates can also serve as sole carbon sources with $\left(\mathrm{NH}_{4}\right)_{2} \mathrm{SO}_{4}$ as the nitrogen source.

All cultures are susceptible to $\mathrm{HgCl}_{2}(1: 5,000)$, and most are suscpetible to chloromycetin (30 $\mathrm{U})$. Generally resistant to penicillin $(10 \mathrm{U})$, ampicillin (30 U), tetracycline (30 U), 2,4-diamino6,7-diisopropyl pteridine (Vibriostat $\mathrm{O} / 129$ ), no- 
vobiocin (30 U), streptomycin $(10 \mu \mathrm{g})$, bacitracin (10 U), nalidixic acid (30 U), and neomycin (30 $\mathrm{U})$.

Growth occurs from pH 5 to 9 in Casamino Acid medium containing $8 \%$ solar salt. The strains grow in Casamino Acid medium or nutrient broth without added salt or in similar media containing up to $32 \%$ solar salt when incubated at temperatures of 23 to $37^{\circ} \mathrm{C}$. Growth can also occur in media with 3.5 to $20 \%$ solar salt at 15 and $45^{\circ} \mathrm{C}$. Optimum conditions for growth on complex media are 3.5 to $8 \%$ solar salt (wt/ vol) at 30 or $37^{\circ} \mathrm{C}$.

The G+C content of the DNA is $60.5 \pm 0.5$ mol\%.

The type species is $H$. elongata sp. nov.

Halomonas elongata sp. nov. (e-lon.ga'ta. L. fem. part. adj. elongata elongated, stretched out).

Inasmuch as the genus currently contains only one species, the description of this species is the same as that given above for the genus.

The type strain of $H$. elongata is 1H9, a culture of which has been deposited in the American Type Culture Collection (ATCC 33173). It, along with most of the strains, possesses urease and liquefies gelatin. The only distinguishing characteristics noted, so far, are that it is able to produce slight visible growth at $4^{\circ} \mathrm{C}$ and survives $45^{\circ} \mathrm{C}$ in 8 to $20 \%$ solar salt.

Strain 1H15 (ATCC 33174) is regarded as belonging to a biovar of this species because its cells are lophotrichous and it is unable to grow at $37^{\circ} \mathrm{C}$ in the presence of $32 \%$ solar salt.

\section{ACKNOWLEDGMENTS}

We thank R. Hakkenberg and the employees of the Antilles International Salt Co. facility on Bonaire, Netherlands Antilles, for their patience and help during the field collections. Special gratitude is also due to investigators at the University of Maryland; R. R. Colwell, for supplying the computer time and programs; K. Lee, University of Nebraska, for the transmission electron microscopic thin sections; L. Hilsabeck for the scanning electron microsopy pictures (Fig. 1); M. Leddy and L. A. Kiefer for technical assistance; and D. Kronish, Warner-Lambert Co., who generously donated the Patho-Tec identification materials.

This research was funded by a contract from the International Salt Co., Clarks Summit, $\mathrm{Pa}$., and by grants from the Center for Coastal and Environmental Studies, Rutgers-The
State University; the Water Resources Center, University of Nebraska-Lincoln; and the University of Nebraska Research Council grants 85-010-442-59 and 85-010-442-81.

\section{REPRINT REQUESTS}

Address reprint requests to: Dr. Carol D. Litchfield, Haskell Laboratory, E. I. du Pont de Nemours \& Co., Wilmington, DE 19898.

\section{LITERATURE CITED}

1. Buchanan, R. E., and N. E. Gibbons (od). 1974. Bergey's manual of determinative bacteriology, oth ed. Williams and Wilkins Co., Baltimore.

2. Colwell, R. R., C. D. Litchfield, R. H. Vreeland, L A. Kiefer, and N. E. Gibbons. 1979. Taronomic stùdies of red halophilic bacteria. Int. J. Syst. Bacteriol. 29: 379-399.

3. Gibbons, N. E. 1969. Isolation, growth and requirements of halophilic bacteria, p. 169-183. In J. R. Norris and D. W. Ribbons (ed.), Methods in microbiology, 3B. Academic Press Inc., New York.

4. Hespell, R. B. 1977. Serpens flexibilis, gen. nov., sp. nov., an unusually flexible, lactate-oxidizing bacterium. Int. J. Syst. Bacteriol. 27:371-381.

5. Holding, A. J., and J. G. Collee. 1971. Routine biochemical tests, p. 1-33. In J. R. Norris and D. W. Ribbons (ed.), Methods in microbiology, 6A. Academic Press Inc., New York.

6. Hugh, R., and E. Leifoon. 1953. The taxonomic significance of fermentative versus oxidative metabolism of carbohydrates by various gram-negative bacteria. J. Bacteriol. 66:24-26.

7. Hylemon, P. B., J. S. Wells, N. R. Krieg, and H. W. Jannasch. 1973. The genus Spirillum: a taxonomic study. Int. J. Syst. Bacteriol. 23:340-380.

8. Krieg, N. R., and P. B. Hylemon. 1976. The taxonomy of the chemoheterotrophic spirilla. Annu. Rev. Microbiol. 30:303-325.

9. Larsen, H. 1967. Biochemical aspects of extreme halophilism. Adv. Microb. Physiol. 1:97-132.

10. LeFevre, E., and L. A. Round. 1919. A preliminary report upon some halophilic bacteria. J. Bacteriol. 4: 177-182.

11. Mandel, M., L Igambi, J. Bergendahl, M. L. Dodson, Jr., and E. Scheligen. 1970. Correlation of melting temperature and cesium chloride buoyant density of bacterial deoxyribonucleic acid. J. Bacteriol. 101:333338.

12. Marmur, J. 1961. A procedure for the isolation of DNA from microorganisms. J. Mol. Biol. 3:208-218.

13. Matheson, A. T., G. D. Sprott, I. J. McDonald, and H. Tessier. 1976. Some properties of an unidentified halophile: growth characteristics, internal salt concentration, and morphology. Can. J. Microbiol. 22:780-786.

14. Skerman; V. B. D. 1967. A guide to the identification of the genera of bacteria, 2nd ed. Williams and Wilkins Co., Baltimore, Md. 